Vol 5. No 2. Agustus 2021

ISSN 2580-5029

\title{
Inventarisasi Tumbuhan Akuatik Berpotensi Fitoremediator Air Limbah Industri di Waduk Bunder Gresik
}

\author{
Muhammad Badrut Tamam ${ }^{\text {* }}$, Aisyah Hadi Ramadani 1, Eti Milhatul Maflahah Halma 1, \\ Chandra Tri Uliana Sari ${ }^{1}$
}

${ }_{1}^{1}$ Program Studi Biologi, Fakultas Sains Teknologi dan Pendidikan, Universitas Muhammadiyah Lamongan, Jl. Raya Plalangan Plosowahyu KM.3 Lamongan Jawa Timur, Indonesia 62218

*mh.badruttamam@gmail.com

\begin{abstract}
The Bunder Reservoir Ecosystem is composed of various components, both biotic and abiotic. One of the components contained in the reservoir is aquatic plants as phytoremediator for wastewater. The aquatic plant inventory in the Bunder Reservoir aims to determine the diversity of aquatic plant species that have the potential to phytoremediate industrial waste. The research design was descriptive qualitative exploratory. Aquatic plant species were collected using a subjective estimates method with visual techniques. In the waters of the Bunder Reservoir, 17 species of aquatic plants from 13 families were found, including 11 emergent types, 1 free floating, 4 rooted floating, and 1 submersed. Types that have the potential to act as phytoremediators for inorganic waste in the metal categories are A. philoxeroides, A. sessilis, Cyperus sp. Hygrophila sp., I. carnea, I. aquatic, L. perpusilla, N. nucifera, Nymphaea sp., N. indica, P. barbata, and T. latifolia. The aquatic plant that has the potential for phytoremediator of pesticide waste is L. adscenden. While S. sesban tends to remove oil pollutants. Organic waste degrading species consist of T. latifolia, L. perpusilla, I.aquatica, Cyperus sp., And Brachiaria sp.
\end{abstract}

Keywords: species diversity, aquatic plant, phytoremediator, heavy metal

\begin{abstract}
ABSTRAK
Ekosistem Waduk Bunder tersusun dari berbagai komponen baik biotik maupun abiotik. Salah satu komponen yang terdapat dalam waduk tersebut adalah tumbuhan akuatik sebagai fitoremediator air limbah. Inventarisasi tumbuhan akuatik di Waduk Bunder bertujuan untuk mengetahui diversitas spesies tumbuhan akuatik yang berpotensi fitoremediasi limbah industri. Desain penelitian berupa deskriptif kualitatif yang bersifat eksplorasi. Pendataan spesies tumbuhan akuatik dilakukan menggunakan metode subjective estimates dengan teknik visual. Pada perairan Waduk Bunder ditemukan 17 spesies tumbuhan akuatik dari 13 familia yang mencakup 11 tipe emergent, 1 free floating, 4 rooted floating, dan 1 submersed. Jenis yang berpotensi sebagai fitoremediator limbah anorganik golongan logam terdiri dari A. philoxeroides, A. sessilis, Cyperus sp. Hygrophila sp., I. carnea, I. aquatic, L. perpusilla, N. nucifera, Nymphaea sp., $N$. indica, P. barbata, dan T. latifolia. Tumbuhan akuatik yang berpotensi fitoremediator limbah pestisida adalah $L$. adscenden. Sedangkan $S$. sesban cenderung sebagai penghilang polutan minyak. Spesies pendegradasi limbah organic terdiri dari T. latifolia, L. perpusilla, I.aquatica, Cyperus sp., dan Brachiaria sp.
\end{abstract}

Kata Kunci: diversitas spesies, tumbuhan akuatik, fitoremediator, logam berat 
Biotropic Tahun 2021, Vol.5 (No.2): 68 - 73 Inventarisasi Tumbuhan Akuatik Berpotensi Fitoremediator Air Limbah Industri di Waduk Bunder Gresik

\section{PENDAHULUAN}

Kabupaten Gresik mengalami perkembangan pembangunan industri yang cukup signifikan. Data Dinas Koperasi, UKM, Perindustrian, dan Perdagangan Kabupaten Gresik Tahun 2017, setidaknya terdapat 6.495 industri yang berada di Kabupaten Gresik. Tingginya sektor industri ini memiliki dampak terhadap sosial ekonomi dan lingkungan dimana keduanya saling bertolak belakang. Perekonomian meningkat akan tetapi lingkungan semakin rusak akibat pencemaran limbah yang masuk ke ekosistem.

Waduk Bunder merupakan salah satu waduk yang terletak di tengah kota Gresik dan dimanfaatkan untuk berbagai sektor seperti pertanian. Berdasarkan Peraturan Bupati Gresik Nomor 3 Tahun 2015, Waduk Bunder ditetapkan sebagai penguasaan Pemerintah Kabupaten Gresik di bawah pengawasan Dinas Pekerjaan Umum Bidang Pengairan. Waduk ini diperuntukkan sebagai Sumber Daya Air.

Ekosistem Waduk Bunder tersusun dari berbagai komponen baik biotik maupun abiotik. Salah satu komponen yang terdapat dalam waduk tersebut adalah tumbuhan akuatik yang memiliki kemampuan sebagai fitoremediator air limbah. Inventarisasi tumbuhan akuatik di Waduk Bunder merupakan langkah awal untuk mengetahui potensi tumbuhan akuatik apa saja yang memiliki kemampuan fitoremediasi limbah industri.
Tumbuhan akuatik disebut juga dengan tumbuhan air dan hidrofit. Habitat tumbuhan akuatik yakni berada di lingkungan sekitar air atau di dalam air yang memiliki peranan sebagai produsen energi di suatu ekosistem (Odum dan Barrett, 2005). Fungsi tumbuhan akuatik dalam suatu ekosistem berperan sebagai fitoplankton yang berfungsi sebagai produsen awal rantai makanan di perairan, alga dan tumbuhan berbunga yang berfungsi sebagai tempat ikan berlindung, serta habitat bagi burung dan kehidupan liar lainnya, menyerap nutrisi, menetralisir polutan, penghasil oksigen bagi organisme heterotrof, menstabilkan dasar perairan dan sebagai tumbuhan hias. Selain memiliki peranan dan fungsi secara ekologis, tumbuhan akuatik memiliki manfaat sebagai sumber pangan, obat-obatan, dan agen fitoremeditor.

Tumbuhan akuatik dapat dibagi menjadi beberapa kelompok, yakni: Submersed plants, tumbuhan akuatik yang akarnya berada di dasar perairan serta tumbuh melewati bagian permukaan air yang ditandai dengan ciri bunga atau tangkai bunga muncul di bagian atas permukaan air. Free floating plants, tumbuhan akuatik yang hidupnya mengapung di permukaan air yang mana akar berada di dasar perairan, pada umumnya tumbuh pada perairan yang nutrisinya banyak. Rooted floating plants, tumbuhan akuatik yang memiliki batang di bagian bawah permukaan dengan sistem pertunasan, pada umumnya daun serta bunga mengapung di bagian dasar perairan dengan 
Biotropic Tahun 2021, Vol.5 (No.2): 68 - 73

Inventarisasi Tumbuhan Akuatik Berpotensi Fitoremediator Air Limbah Industri di Waduk Bunder Gresik

kedalaman hingga 4-5 kaki. Emergent plants, tumbuhan akutik yang berada di tepi dengan ciri-ciri secara umum memiliki sistem perakaran yang berada di atas permukaan air (Lembi, 2009).

Fitoremediasi merupakan usaha mendekontaminasi limbah di tanah maupun air yang meliputi pencucian, penghancuran, inaktivasi, atau imobilisasi dengan memanfaatkan kemampuan tanaman untuk menyerap zat kontaminan tersebut (Astuti \& Indriatmoko, 2018; Herlambang \& Suryati, 2018). Proses fitoremediasi cemaran air limbah terdiri dari beberapa tahapan yaitu Phytoextraction - proses penarikan limbah kontaminan oleh akar dari media pertumbuhan dan diakumulasikan di sekitar akar. Rhizofiltrattion - proses penyerapan atau pengendapan zat kontaminan di bagian akar tumbuhan. Phytostabilization - proses pengurangan mobilitas limbah kontaminan di media pertumbuhan melalui penyerapan oleh akar dan limbah diikat oleh sel-sel akar sehingga tidak terlepas oleh erosi. Rhyzodegradation - proses penguraian limbah kontaminan oleh mikroorganisme yang bersimbiosis dengan akar tumbuhan. Phytodegradation - proses penguraian limbah kontaminan oleh tumbuhan yang dibantu oleh enzim tertentu seperti enzim oksigenasi dan dehalogenase. Phytovolatization - proses penarikan dan transpirasi limbah kontamnian oleh tumbuhan dalam bentuk zat yang telah terurai oleh proses sebelumnya dan diuapkan ke atmosfer (Martin, 2019)
Penggunaan fitoremediasi memiliki beberapa keuntungan yaitu mudah, sederhana, dan biaya penerapan yang rendah (Cahyanto dkk., 2018). Nizam et al., (2020) membuktikan penggunaan jenis tumbuhan air yaitu Eichhornia crassipes dan Ipomoea aquatica terbukti efektif untuk mengurangi kadar pencemar dalam air. E. crassipes mampu mereduksi kadar fosfat terlarut sedangkan $I$. aquatica mengurangi $92,6 \%$ total padatan terlarut dan 82,7\% kandungan nitrogen ammonia. Tingginya kemampuan dua spesies tersebut dalam meremediasi polutan didukung oleh sifat cepat tumbuh (fast growing plant).

\section{METODE}

Inventarisasi tumbuhan akuatik berpotensi sebagai fitoremediasi air limbah industri di waduk bunder gresik dilaksanakan pada bulan September - Januari 2020. Penelitian dilakukan di Waduk Bunder Gresik dengan koordinat $7^{\circ} 10^{\prime} 23.09 " S$, $112^{\circ} 35^{\prime} 31.13 " \mathrm{E}$.

Desain penelitian berupa deskriptif kualitatif yang bersifat eksplorasi dengan bentuk studi lapangan. Berdasarkan pengertian Siyoto dan Sodik (2015) yang disesuaikan dengan variablel penelitian ini, deskriptif kualitatif merupakan penelitian yang menggambarkan fenomena hadirnya tumbuhan akuatik di Waduk Bunder Gresik secara alamiah tanpa adanya perlakuan khusus yang sengaja dilakukan untuk mengondisikan kehadiran tumbuhan tersebut. 
Biotropic Tahun 2021, Vol.5 (No.2): 68 - 73 Inventarisasi Tumbuhan Akuatik Berpotensi Fitoremediator Air Limbah Industri di Waduk Bunder Gresik

Pendataan spesies tumbuhan akuatik dilakukan menggunakan metode subjective estimates dengan teknik visual (Madsen and Wersal, 2017) yang dikombinasi foto aerial wahana drone. Teknik ini direkomendasikan untuk pengamatan ketiga jenis tumbuhan akuatik. Drone diterbangkan pada 6 titik stasiun pengamatan sebagai titik sampling. Seluruh tumbuhan yang teramati

diidentifikasi dari famili hingga spesies dan bentuk tumbuhnya.

\section{HASIL DAN PEMBAHASAN}

Tumbuhan akuatik yang berhasil diinventarisasi di Waduk Bunder tercantum pada tabel 1. Total ditemukan 17 spesies tumbuhan akuatik dari 13 familia yang mencakup 11 tipe emergent, 1 free floating, 4 rooted floating, dan 1 submersed.

Tabel 1. Daftar tumbuhan akuatik

\begin{tabular}{llc}
\hline \multicolumn{1}{c}{ Nama Ilmiah } & \multicolumn{1}{c}{ Familia } & Tipe \\
\hline Alternanthera philoxeroides & Amaranthaceae & $\mathrm{E}$ \\
Alternanthera sessilis & Amaranthaceae & $\mathrm{E}$ \\
Brachiaria sp. & Poaceae & $\mathrm{E}$ \\
Corchorus trilocularis & Malvaceae & $\mathrm{E}$ \\
Cyperus sp. & Cyperaceae & $\mathrm{E}$ \\
Hygrophila sp. & Acanthaceae & $\mathrm{S}$ \\
Ipomoea aquatica & Convolvulaceae & $\mathrm{E}$ \\
Ipomoea carnea & Convolvulaceae & $\mathrm{E}$ \\
Lemna perpusilla & Araceae & FF \\
Ludwigia adscenden & Onagraceae & $\mathrm{E}$ \\
Nelumbo nucifera & Nelumbonaceae & $\mathrm{RF}$ \\
Nymphaea nouchali & Nymphaeaceae & $\mathrm{RF}$ \\
Nymphaea pubescens & Nymphaeaceae & $\mathrm{RF}$ \\
Nymphoides indica & Nymphaeaceae & $\mathrm{RF}$ \\
Persicaria barbata & Polygonaceae & $\mathrm{E}$ \\
Sesbania sesban & Fabaceae & $\mathrm{E}$ \\
Typha latifolia & Typhaceae & $\mathrm{E}$ \\
\hline
\end{tabular}

Keterangan : $\mathrm{E}=$ emergent; $\mathrm{FF}$ = free floating; $\mathrm{RF}$ = rooted floating; $\mathrm{S}=$ submersed (Sumber $:$ Data Primer, 2021)

Berdasarkan pemetaan penggunaan lahan, sekitar Waduk Bunder banyak dimanfaatkan sebagai pemukiman, pertokoan, industri, lahan pertanian, dan lahan kosong. Pemukiman dan industri berkontribusi terhadap pencemaran limbah domestic berupa grey water (sabun, deterjen, minyak) dan black water (buangan kakus) yang membawa cemaran bakteri Coliform
(Widiyanto, dkk., 2015). Limbah domestic mengandung amoniak tinggi dan toksik bagi biota perairan (Said dan Sya'bani, 2014; Prayitno dan Sholeh, 2014) selain itu juga komponen fosfor yang menyebabkan eutrofikasi (Sulistia dan Septisya, 2019). Limbah industri menyumbang limbah anorganik berupa logam seperti mercuri (Hg), Khrom (Cr), Kadmium (Cd), timbal (Pb), tembaga (Cu) dan arsen (As) yang akan 
menganggu metabolisme dan terakumulasi dalam makhluk hidup mengikuti rantai makanan (Caroline dan Moa, 2015). Bagian selatan waduk mayoritas berbatasan dengan lahan pertanian. Aktivitas pertanian seperti pemberian pupuk dan insektisida mencemari perairan Waduk yang meningkatkan kadar nitrogen, fosfat, kalium, organofosfat, organoklorin, dan karbamat (Mulyono, 2009; Nugroho, dkk., 2015). Organofosat salah satu zat yang berbahaya bagi kesehatan karena dapat menghambat aktivitas enzim asetilkolinestrase yang menyebabkan kejang dan kelumpuhan (Kadim, dkk., 2013). Bahanbahan pencemar tersebut dapat diremediasi oleh tumbuhan akuatik yang ditemukan pada penelitian ini.

Kemampuan masing-masing tumbuhan berbeda dalam mengakumulasi bahan pencemar. Faktor yang mempengaruhi potensi remediasi pada tumbuhan akuatik diantaranya kecepatan pertumbuhan, struktur anatomi tubuh yang sederhana, laju penyerapan ion substrat ke dalam tubuh, jenis tumbuhan dikotil mampu menyerap pencemar lebih banyak dari monokotil, kandungan kloroplas, konsentrasi pencemar (Notohadiprawiro, 2006; Sa'ad, dkk., 2009). Pada penelitian ini ditemukan beberapa family yang diketahui memiliki kemampuan hyperakumulator logam berat yaitu famili Poacea, Cyperaceae, Fabaceae sesuai dengan penelitian Thampatti et al., (2020).

Alternanthera philoxeroides berdasar catatan Khan et al., (2020) secara spesifik mampu menyerap polutan pewarna industri tekstil golongan remazol red. Pada penelitian ini tumbuhan A. philoxeroides banyak dijumpai pada area yang berdekatan dengan pintu air waduk serta cenderung tumbuh pada zona litoral. Rana dan Maiti (2020) menyatakan bahwa jenis ini dimanfaatkan sebagai tumbuhan penyerap limbah bahan-bahan artifisial. Spesies Alternanthera yang lain yaitu A. sessilis mampu mengakumulasi logam $\mathrm{Pb}$ namun kurang potensial untuk logam $\mathrm{Cr}$ dan Cd (Chinmayee et al., 2014). Kemampuan tersebut merupakan mekanisme pertahanan terhadap stress oksidatif.

Penelitian Nandakumar et al. (2019) menyatakan bahwa genus Brachiaria dapat digunakan untuk menghilangkan fosfor dan nitrogen pada proses wastewater treatment skala industri kecil dan pertanian. Jenis tumbuhan ini dilaporkan tidak memiliki potensi sebagai fitoekstraksi logam berat (Andrade et al., 2014).

Spesies akuatik lain yang tercatat juga memiliki kemampuan removal kelebihan nutrient pertanian yaitu Cyperus sp. Genus Cyperus menurut Fletcher et al. (2020) berpotensi menghilangkan nitrogen, ammonia, dan fosfor berlebih di perairan dengan rata-rata efisiensi 64,5\%,69\%, dan 54\%. Berbeda dengan spesies Corchorus trilocularis, Niazy dan Wahdan (2017) melaporkan bahwa spesies ini kurang berpotensi sebagai fitoremediator. Penelitian yang mereka lakukan dengan perlakuan $\mathrm{Pb}$ tidak diserap efektif oleh genus Corchorus.

Spesies Hygrophila sp. dan Ipomoea sp. telah banyak dikenal sebagai fitoremediator 
logam berat $\mathrm{Zn}, \mathrm{Pb}, \mathrm{Ni}, \mathrm{Cd}$ (Mihaela et al., 2014), dan terutama golongan Kromium (Cr).

I. carnea dan I. aquatica mengakumulasi kromium sebagian besar pada bagian batang, kemudian akar dan daun (Syabani, dkk., 2011). Untuk limbah organic, I. aquatica mampu mereduksi kadar nitrogen dan fosfor (Fletcher et al., 2020).

Lemna perpusilla secara ekologis tumbuhan ini merupakan gulma perairan namun efektif menyerap limbah anorganik logam berat $\mathrm{Cd}, \mathrm{Hg}, \mathrm{Zn}, \mathrm{Mn}, \mathrm{Pb}, \mathrm{Cr}, \mathrm{Cu}, \mathrm{Fe}, \mathrm{Ni}$ dan Ag (Ugya, 2015; Safarrida, 2015; Irawanto dan Munandar, 2017; Daud et al., 2018). Lemna perpusilla secara ekologis bersifat sun loving yaitu membutuhkan paparan intensitas cahaya matahari tinggi untuk menunjang pertumbuhannya. Hal ini terkait dengan distribusi spesies L. perpusilla yang dominan berada di area terbuka di bagian tengah Waduk Bunder. L.perpusilla juga mengubah nitrogen dan fosfor sebagai nutrisi tumbuh sehingga tanaman ini sangat berpotensi untuk mereduksi kelebihan kadar nitrogen dan fosfor di perairan (Astuti dan Indriatmoko, 2018).

Genus Ludwigia merupakan fitoremediator yang efektif untuk menyerap polutan pestisida golongan Atrazine, lambdacyhalothorin. Ludwigia mentranslokasikan senyawa tersebut pada jaringan mesosom tubuhnya (Fletcher et al., 2020).

Nelumbo nucifera dikenal sebagai tumbuhan akuatik yang bersifat hiperakumulasi logam berat dengan spectrum jenis logam yang sangat bervariasi serta toleransi yang tinggi. Nelumbo tercatat dapat mengakumulasi logam golongan $\mathrm{Fe}, \mathrm{Al}, \mathrm{Pb}, \mathrm{Cd}$ (Thampatti et al., 2020), Mn (Obando, 2012), $\mathrm{Cu}, \mathrm{Cr}, \mathrm{Pb}, \mathrm{As}$ (Hamidian et al., 2016) serta golongan Sn (Ashraf et al., 2013). Logam ini ditranslokasikan ke bagian akar, daun, petiole tanpa ada gejala toksisitas.

Genus Nymphaea, termasuk tumbuhan dengan toleransi tinggi terhadap paparan logam berat. Tumbuhan ini mampu mengimobilisasi logam ke kelenjar epidermis daun. Jenis logam yang mampu diakumulasi oleh Nymphaea antara lain $\mathrm{Zn}, \mathrm{Pb}, \mathrm{Fe}, \mathrm{Al}$, dan $\mathrm{Cd}$ (Thampatti et al., 2020). Berbeda dengan Nymphaea, Nymphoides indica tidak mengakumulasi banyak jenis logam. Jenis ini hanya mampu sebagai fitoekstraktor logam $\mathrm{Fe}$, $\mathrm{Al}, \mathrm{Cd}$, dan $\mathrm{Pb}$ yang diakumulasi pada bagian akar (Thampatti et al., 2020). Jenis lainnya yang juga terbatas pada logam tertentu adalah Persicaria barbata. Spesies ini hanya mampu mengakumulasi logam $\mathrm{Pb}, \mathrm{Cu}, \mathrm{Zn}$, dan $\mathrm{Cr}$ (Nazir et al., 2011; Teuchies et al., 2013).

Genus Sesbania yang termasuk dalam family Fabaceae tidak banyak berperan sebagai fitoremediator logam berat, namun berdasarkan penelitian Farhana et al., (2012) tumbuhan ini mampu mendetoksifikasi limbah hidrokarbon dari tumpahan minyak.

Typha latifolia memiliki kemampuan mengabsorbsi dan sangat toleran terhadap kandungan nitrogen tinggi (Khan et al., 2020). Pemanfaatan Waduk Bunder sebagai lahan pertanian saat musim kemarau meningkatkan intake nitrogen ke dalam substrat di perairan. Nitrogen menjadi salah satu komponen pupuk 
yang banyak digunakan oleh masyarakat di sekitar Waduk pada lahan pertanian mereka. Fletcher et al. (2020) mendata bahwa $T$. latifolia juga dapat menghilangkan kelebihan fosfor dalam air dengan efisiensi 81\%. Hal ini memperkuat hasil penelitian ini yang menunjukkan pola distribusi $T$. latifolia cenderung berkoloni di dekat dan bekas lahan pertanian. T. latifolia dalam Rana dan Maiti (2020) digunakan untuk menyerap logam As, $\mathrm{Cd}, \mathrm{Cr}, \mathrm{Cu}, \mathrm{Pb}, \mathrm{Zn}$, dan $\mathrm{Ni}$ yang ada dalam leachate landfill sedangkan Salem et al., (2017) menyatakan jenis ini akumulator Mn.

\section{KESIMPULAN}

Penelitian ini berhasil mendata sebanyak 17 spesies tumbuhan akuatik yang berada di Waduk Bunder, Gresik. Jenis yang berpotensi sebagai fitoremediator limbah anorganik golongan logam terdiri dari $A$. philoxeroides, A. sessilis, Cyperus sp. Hygrophila sp., I. carnea, I. aquatic, L. perpusilla, N. nucifera, Nymphaea sp., Nymphoides indica, Persicaria barbata, dan Typha latifolia. Tumbuhan akuatik yang berpotensi fitoremediator limbah pestisida adalah $L$. adscenden. Sedangkan S.sesban cenderung sebagai penghilang polutan minyak. Spesies pendegradasi limbah organic terdiri dari $T$. latifolia, L. perpusilla, I.aquatica, Cyperus sp., dan Brachiaria sp.

\section{DAFTAR PUSTAKA}

Andrade, A.F.M., Nelson M.B do Amaral Sobrinho. F.S dos Santos. M.O.L. Megalhaes, A Tolon-Beccera, L da Silva
Lima. $\quad 2014 . \quad$ EDTA-induced phytoextraction of lead and barium by brachiaria (B. decumbens cv. Basilisk) in soil contaminated by oil exploration drilling waste. Acta Scientiarum. Agronomy 36(4): 495-500

Ashraf, M.A., Maah J.M., Yusoff I. 2013. Evaluation of Natural Phytoremediation Process Occuring at ex-situ Mining Catchment. Chiang Mai J Sci 40(2): 198213

Astuti L.P. dan Indriatmoko. 2018. Kemampuan Beberapa Tumbuhan Air dalam Menurunkan Pencemaran Bahan Organik dan Fosfat untuk Memperbaiki Kualitas Air. Jurnal Teknologi Lingkungan 19(2): 183-190

Caroline J dan G.A. Moa. 2015. Fitoremediasi Logam Timbal (Pb) Menggunakan Tanaman Melati Air (Echinodorus palaefolius) Pada Limbah Industri Peleburan Tembaga Dan Kuningan. Seminar Nasional Sains dan Teknologi Terapan III : 733-744

Chinmayee D.M., Mary S.A., Mini I, Swapna T.S. 2014. Phytoremediation Potential and Antioxidant Responses in Alternanthera sessilis (L) R.BR. Journal of Aquatic Biology and Fisheries 2 : 114-118.

Daud, M.K., S. Ali., Z. Abbas, I.E. Zaheer, M.A. Riaz, A. Malik, A. Hussain, M.Rizwan, M. Zia-ur-Rehman, S.J. Zhu. 2018. Potential of Duckweed (Lemna minor) for the Phytoremediation of Landfill Leachate. Journal of Chemistry 2018: 1-9. https://doi.org/10.1155/2018/3951540

Farhana M, Zhenyu W, Ying X, Jian Z, Dongmei G, Yang-Guo Z, Zulfiqar AB, Baoshan X .2012. Rhizodegradation of petroleum hydrocarbons by Sesbania cannabina in bioaugmented soil with free and immobilized consortium. J Hazard Mater $30: 262-269$

Fletcher J., N. Willby, D.M. Oliver, R.S. Quilliam. 2020. Phytoremediation Using Aquatic Plants. Phytoremediation In-situ 
Applications Chapter 7. Springer Nature Switzerland. Switzerland

Hamidian AH, Norouznia H, Mirzaei R. 2016. Phytoremediation efficiency of Nelumbo nucifera in removing heavy metals $(\mathrm{Cu}, \mathrm{Cr}$, $\mathrm{Pb}$, As and $\mathrm{Cd}$ ) from water of Anzali wetland. J Ecol Nat Environ 69(3):633643

Irawanto, R., A A Munandar. 2017. Kemampuan tumbuhan akuatik Lemna minor dan Ceratophyllum demersum sebagai fitoremediator logam berat timbal (Pb). Pros Sem Nas Masy Biodiv Indon 3(3): 446-452.

Kadim M.K., S. Sudaryanti, W. Endang Y. H. 2013. Pencemaran Residu Pestisida di Sungai Umbulrejo Kecamatan Dampit Kabupaten Malang. J. Manusia dan Lingkungan 20 (3):262-268.

Khan, M.I., S.A Cheema, S.Anum, NK Niazi, M.Azam, S.Bashir, I Ashraf, R.Qadri. 2020. Phytoremediation of Agricultural Pollutans. Phytoremediation In-situ Applications Chapter 2. Springer Nature Switzerland. Switzerland

Khan, M.I., S.A. Cheema, S.Anum, N.K Niazi, M.Azam, S. Bashir, I. Ashraf, R. Qadri. 2020. Phytoremediation of Agricultural Pollutants. Phytoremediation, Concepts and Strategies in Plant Sciences Chapter 2. Springer Nature. Switzerland.

Martin, Artho Nugraha. 2019 . Fitoremediasi Logam Besi (Fe) Pada Air Eks Galian Pasir Kecamatan Pasir Sakti Kabupaten Lampung Timur Menggunakan Eceng Gondok Eichhornia crassipes (Martius, 1824). Skripsi. Fakultas pertanian. Universitas Lampung. Bandar Lampung.

Mihaela C., Corneau C.G., Craciun C., Tripon S. 2014. Phytoremediation Of Some Heavy Metals And Radionuclides From A Polluted Area Located On The Middle Jiu River. Case Study: Typha Latifolia L. Muzeul Olteniei Craiova. Oltenia. Studii și comunicări. Ştiinţele Naturii. Tom 30(2): 209-221
Mulyono, D. 2009. Pencemaran Pestisida Dalam Budidaya Pertanian dan Upaya Pengendaliannya. JRL 5(3): 219-224.

Nandakumar S, Pipil H, Ray S, Haritash AK (2019) Removal of phosphorous and nitrogen from wastewater in Brachiariabased constructed wetland. Chemosphere 233:216-222

Niazy M.M., dan M.E.M. Wahdan. 2017. Enhanching Phytoremediation of $\mathrm{Pb}$ by Treating Soil With Citric Acid and Growing White Jute (Corchorus capsularis, L.) and River Red Gum (Eucalyptus camaldulensis). Zagazig J.Agric.res 44(4): 1359-1367.

Nizam, N.U.M., M.M. Hanafiah, I.M. Noor, H.I.A. Karim. 2020. Efficiency of Five Selected Aquatic Plants in Phytoremediation of Aquaculture Wastewater. Appl. Sci. $10(2712): 1-11$.

Notohadiprawiro. 2006. Logam Berat dalam Pertanian. Ilmu Tanah Universitas Gadjah Mada. Yogyakarta.

Nuhgroho, B.Y.H., S.Y. Wulandari, A.Ridlo. 2015. Analisis Residu Pestisida Organofosfat di Perairan Mlonggo Kabupaten Jepara. Jurnal Oseanografi 4(3):541-544.

Obando WSO. 2012. Evaluation of sacred lotus (Nelumbo nucifera Gaertn.) as an alternative crop for phyto-remediation. Ph. D. thesis, Auburn University, Auburn, Alabama, $193 \mathrm{p}$

Prayitno dan M. Sholeh. 2014. Pengurangan Nitrogen Pada Limbah Cair Terolah Industri Penyamakan Kulit Menggunakan Sistem Wetland Buatan. Majalah Kulit, Karet, dan Plastik 30(2):79-86.

Sa'ad, N.S, R. Artanti, T. Dewi. 2009. Fitoremediasi untuk Rehabilitasi Lahan Pertanian Tercemar Kadminum (Cd) dan Tembaga (Cu). Jurnal Tanah dan Iklim 30: 59-66

Safarrida A, Ngadiman, Jaka. 2015. Fitoremediasi kandungan kromium pada 
limbah cair menggunakan tanaman air. Jurnal Bioteknologi dan Biosains 2 (2): 55-59.

Said, N.I., dan M.R. Sya'bani. 2014. Penghilangan Amoniak di Dalam Air Limbah Domestik Dengan Proses Moving Bed Biofilm Reactor (MBBR). JAI 7 (1): 4465.

Salem, Z.B., Laffray, X., Al-Ashoor, A., Ayadi H, Aleya, L., 2017. Metals and metalloid bioconcentrations in the tissues of Typha latifolia grown in the four interconnected ponds of a domestic landfill site. J Environl Sci, 54: 56-68. DOI: 10.1016/j.jes.2015.10.039

Sulistia S dan A.C. Septisya. 2019. Analisis Kualitas Air Limbah Domestik Perkantoran. JRL 12(1):41-57.

Syabani, M.W., F. Nugraha, Noodiyanto. 2011. Potensi Phytoremediation dari Ipomoea aquatica untuk Air Terkontaminasi Kromium Valensi Enam. Prosiding Workshop Penelitian dan Pengembangan Kulit, Karet, dan Plastik. Yogyakarta

Thampatti, K.C., V.I. Beena, A.V. Meera, A.S. Ajayan. 2020. Phytoremediation of Metals by Aquatic Macrophytes. Phytoremediation In-situ Applications Chapter 6. Springer Nature Switzerland. Switzerland

Teuchies, J., Jacobs, S., Oosterlee, L., Bervoets, L., \& Meire, P. 2013. Role of plants in metal cycling in a tidal wetland: Implications for phytoremidiation. Science of the Total Environment, 445 446(2013),146-154. https://doi.org/10.1016/j.scitotenv.201 $\underline{2.11 .088}$

Ugya A. 2015. The efficiency of Lemna minor in the phytoremediation of romi stream: a case study of kaduna refinery and petrochemical company polluted stream. J Appl Biol Biotechnol 3 (1): 11-14

Widiyanto A.F., S.Yuniarno, Kuswanto. 2015. Polusi Air Tanah Akibat Limbah Industri dan Limbah Rumah Tangga. Kesmas 10(2): 246-254. 